\title{
A Meta-Analysis on the Relationship Between Hair Dye and the Incidence of Non-Hodgkin's Lymphoma
}

\author{
Ling Qin ${ }^{a}$ Hui-Yang Deng ${ }^{a}$ Sheng-Jiang Chen ${ }^{b}$ Wei Wei $^{a}$

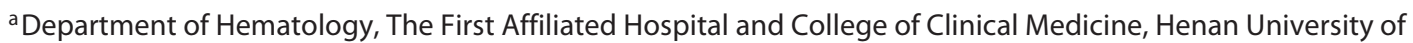

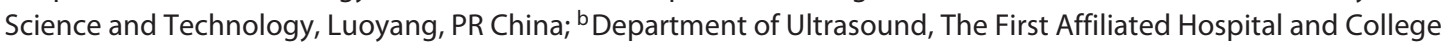 \\ of Clinical Medicine, Henan University of Science and Technology, Luoyang, PR China
}

\section{Significance of the Study}

- This study was aimed at analyzing the association between use of hair dyes and the pathogenesis of non-Hodgkin's lymphoma (NHL) based on published research. Basic research indicates that ingredients in hair dyes increase the risk of NHL and clinical studies suggest that hair dyes are risk factors for NHL, especially in women.

\section{Keywords}

Hair dye · Non-Hodgkin's lymphoma $\cdot$ Meta-analysis

\begin{abstract}
Background: Epidemiologic studies have suggested hair dye to be a risk factor for many cancers. However, previous studies on the association between the personal use of hair dye and risk of non-Hodgkin's lymphoma (NHL) have been inconclusive. Methods: The PubMed, Embase, Cochrane Library, and Web of Science databases, as well as the references cited in included studies, were searched for relevant studies up to February 10, 2015. Odds ratios (OR) with $95 \%$ confidence intervals $(\mathrm{Cl})$ were applied to assess the strength of the association. Publication bias was evaluated using a funnel plot by Egger's and Begg's tests. Results: A total of 16 studies were included in the analysis, including 13 case-control studies and 3 cohort studies. The present meta-analysis results revealed that the risk of $\mathrm{NHL}$ in a high population of
\end{abstract}

hair dye users was 14\% (OR 1.14, 95\% Cl 1.01-1.29). Furthermore, individuals who used more than 20 pack-years of hair dye had increased risk of NHL. Conclusion: The outcomes indicate that hair dye use increases the risk of NHL, especially for females. Hence, people who frequently use hair dyes or have been using hair dyes for more than 20 years should minimize their exposure to hair dye products to prevent the risk of NHL.

(C) 2018 The Author(s)

Published by S. Karger AG, Basel

\section{Introduction}

Non-Hodgkin's lymphoma (NHL) is a malignant tumor that originates from lymph nodes and lymphoid tissues. In recent years, the global morbidity of NHL has exhibited a tendency for gradual increase [1]. Although previous studies have found that infection, drugs, and immunity play a significant role in NHL-generating pro- 
cesses [2], merely a small part of NHL cases can be explained, and researchers continue to fail to fully explain the pathogenesis of NHL.

As a hairdressing product, hair colorants are popular worldwide, and consumers of these products in China are also increasing. These can be classified as temporary hair colorants, semipermanent hair colorants, and permanent hair colorants. This differentiation is mainly based on the diverse chemical ingredients, including phenylamine derivatives, hydrogen peroxide oxidants, and $\mathrm{p}$-aminophenol, etc. [3]. According to genotoxicity studies and animal experiments, hair colorants contain ingredients with potential carcinogenic risks [4-6].

In the past 20 years, epidemiological investigations have indicated that the application of hair colorants is associated with the development of carcinoma of the urinary bladder, breast cancer, and hematological malignancy [7-9]. In a study conducted by Grodstein et al. [10] no association was found between the risk of developing NHL and hair colorants. However, a 15 -year case control study carried out by Zhang et al. [11] suggested that hair colorants may be considered as playing a role in the development of NHL. The possible factors that gave rise to such a difference between these 2 studies are research methodology, subject selection, scale, classification of hair colorants, and frequency of use. Consequently, it remains disputed whether the use of hair colorants increases the onset risk of NHL. This study describes a metaanalysis on relevant publications with the objective of ascertaining whether the use of hair colorants is a risk factor for onset of NHL.

\section{Materials and Methods}

Article Retrieval Strategy in Line with the "PICOS" Principle

Article retrieval was performed by 2 independent researchers. The following key words were used for the search: (Non-Hodgkin lymphoma OR Lymphoma OR NHL) AND (hair dye OR hair colorants OR hair coloring OR hair coloring agent OR hair color/ colour) AND (risk OR incidence) AND (cohort OR case-control study). The PubMed, Embase, Cochrane Library, and Web of Science databases were searched using these key words in the English and Chinese language to collect articles relevant to case control studies and/or cohort studies related to NHL and hair colorants. No language or data limits were set. Furthermore, the bibliographies of all incorporated articles were also retrieved.

\section{Inclusion and Exclusion Criteria}

The articles incorporated in the present study conformed to the following standards: (i) the study should be a case control and/or cohort study; (ii) hair colorant use and NHL risk factors should be evaluated in these articles; (iii) odds ratio (OR) and 95\% confi- dence interval (CI) for exposure factors should be provided in the articles, or raw data should be provided for calculating the OR and $95 \% \mathrm{CI}$, and (iv) in terms of reports from diverse years on an identical study, the latest or best report should be adopted. Articles that were excluded from our study included: those with unavailable raw data; articles which presented animal experiments; reviews or duplicate publications; articles that did not distinguish HL from NHL, or for which NHL was not an outcome indicator. If bifurcation occurred during the collection of articles, corresponding guidance was provided by a third researcher to reach a conclusion based on consensus.

Data Extraction and Quality Assessment

The extracted data should include the name of the first author, publication time, region, research duration, type of study design, gender, age, sample size and control groups, and regulation factors. Finally, cross-footing was carried out; the data were assessed by a third assessor to correct possible errors. For disputes, relevant specialists were consulted for settlement.

The assessors conducted methodological quality assessments from 3 perspectives: study population selection, comparability among groups, and exposure factor measurement of the incorporated articles. These were performed in strict accordance with the Newcastle-Ottawa Scale. Finally, a subgroup analysis was performed in terms of hair colorant usage type, gender, region, article research type, and quality grading for selected studies.

\section{Statistical Analysis}

The low morbidity and relative risk of NHL reported by the cohort studies was roughly equivalent to the ORs of the case control study. Hence, the cohort and case control studies were combined, and the unadjusted and adjusted ORs were all applied into the meta-analysis. In one study, OR was considered as a generic term signifying the relative risk, risk ratio (RR), and rate ratio [12].

Each effect size of this study was based on the calculated and adjusted OR and 95\% CI, while a fixed or random-effects model on heterogeneity was adopted, which was analyzed by Q-test and $I^{2}$. A heterogeneity $Q$-test without statistical significance $\left(p>0.05\right.$ or $I^{2}$ $<25 \%$ ) indicates that preferable consistency exists among researches. Hence, the Mantel-Haenszel method of the fixed-effects model or DerSimonian-Laird method of the random-effects model could be employed [13]. The statistical analysis for all data was performed on Stata 12.0 (Stata, College Station, TX, USA), together with the sensitivity analysis of all incorporated articles. In addition, a funnel plot and Egger's/Begg's correlation tests were used to assess whether any bias was present in the incorporated articles [14].

\section{Results}

\section{Article Retrieval and Screening}

The present analysis was associated with 303 research articles related to hair colorants and NHL. Among these, 12 articles were in Chinese, while 291 articles were in English. Conforming to the incorporation of articles and exclusion criteria, 255 overviews or case reports and irrelevant articles were excluded after preliminary screening 
Fig. 1. Flow chart of the screening of arti-

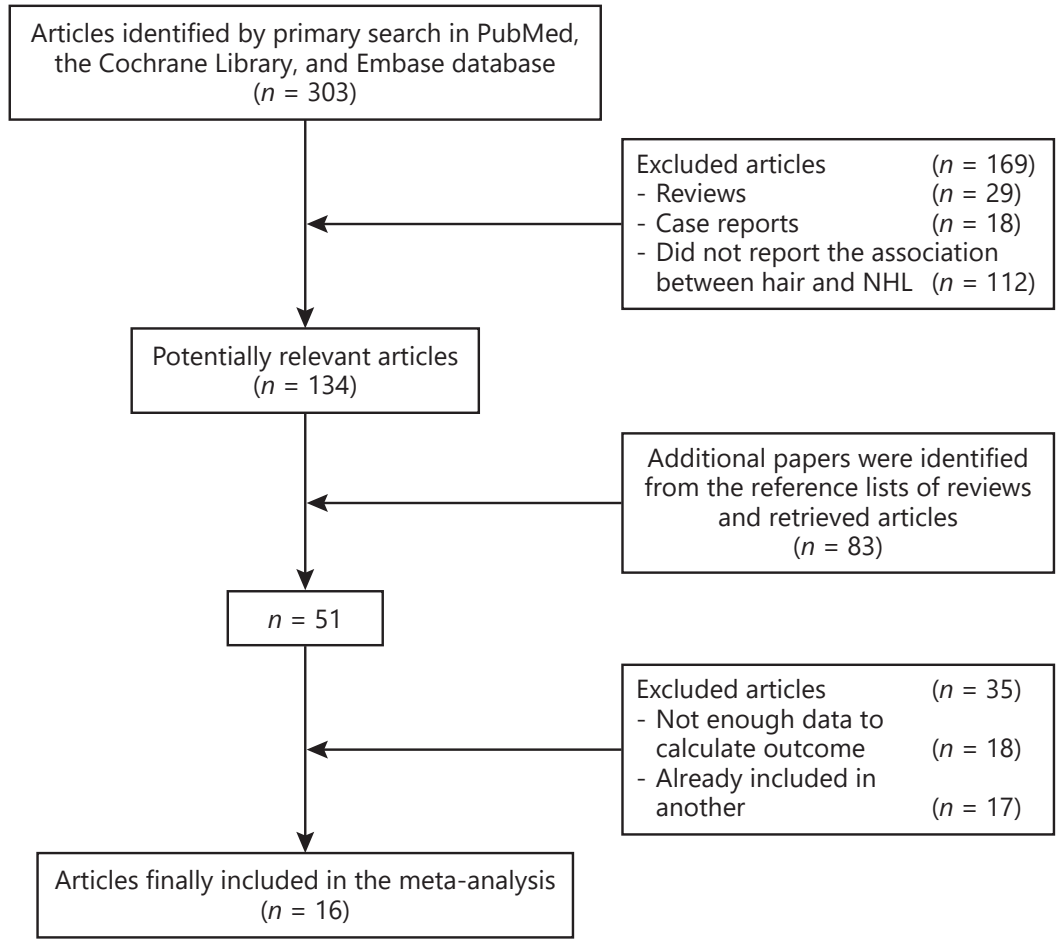
cles.

by reading the titles and abstracts. Furthermore, 53 related articles were additionally incorporated, including 8 articles that provided no accurate and detailed data, 13 articles that considered HL as the outcome indicator, 12 articles that pertained to other diseases, and 4 articles that did not provide $95 \%$ CI of OR/RR. After the collection and settlement of articles, a total of 16 were found to be consistent with the analysis in the present study. Among these articles, 13 were case control studies $[6,7,15-25]$, while the remaining 3 articles were cohort studies. Details for retrieval and screening are presented in Figure 1.

\section{Document Characteristics}

For the fundamental characteristics of these 16 incorporated articles, the corresponding details are presented in Tables 1 and 2. The fixed number of years of publication ranged from 1988 to 2015 for all included articles, in which 3 were from Asia, 9 were from North America, and 4 were from Europe. In terms of study type, 13 articles were case control studies (Table 1) and 3 articles were cohort studies (Table 2). These 13 case control studies included a total of 10,399 patients and 20,013 controls. In addition, subjects in 5 control groups were inpatients, while subjects in 8 groups were from the general population. This study involved 720,019 research participants (including those using or not using hair colorants), and the duration of the follow-up visits lasted for 4-24 years. In addition, $928 \mathrm{NHL}$ cases were also reported. Concerning the meta-analysis, the corrected OR and its 95\% CI were extracted from 3 articles. Three articles provided complete data in relation to females, 2 were targeted at males, and the remaining 11 contained data for both females and males. The details are presented in Tables 1 and 2.

For the definite NHL diagnosis incorporated in the articles, this was performed through case history and pathologic histology. For the adoptions of hair colorants, 6 items were in the form of a questionnaire, 4 items were in the form of telephone follow-up investigations, and 6 items were in the form of face-to-face surveys (Tables 1 and 2).

\section{Relationship between Hair Colorant Use and NHL \\ Risk Assessment}

The Q-value for the 13 case control study articles incorporated in this study was 123.4 through the heteroge- 
Table 1. Case control study features of hair colorant use and NHL

\begin{tabular}{|c|c|c|c|c|c|c|c|c|c|c|c|}
\hline Study & Region & $\begin{array}{l}\text { Research } \\
\text { period }\end{array}$ & $\begin{array}{l}\text { Gen- } \\
\text { der }\end{array}$ & $\begin{array}{l}\text { Age, } \\
\text { years }\end{array}$ & Source of cases & $\begin{array}{l}\text { Source of } \\
\text { control } \\
\text { group }\end{array}$ & $\begin{array}{l}\text { Cases/ } \\
\text { controls, } \\
n\end{array}$ & $\begin{array}{l}\text { NHL } \\
\text { evaluation } \\
\text { criteria }\end{array}$ & $\begin{array}{l}\text { Hair colorant } \\
\text { use evaluation } \\
\text { standard }\end{array}$ & $\begin{array}{l}\text { Adjust- } \\
\text { ment } \\
\text { factor }\end{array}$ & $\begin{array}{l}\text { Newcastle- } \\
\text { Ottawa } \\
\text { Scale } \\
\text { quality } \\
\text { score }\end{array}$ \\
\hline $\begin{array}{l}\text { Schroeder } \\
{[15], 2002}\end{array}$ & USA & $\begin{array}{l}1980- \\
1983\end{array}$ & M & $>30$ & $\begin{array}{l}\text { Iowa State Health } \\
\text { Registration Center; } \\
\text { Occupational and } \\
\text { Environmental Health } \\
\text { Research Center of the } \\
\text { University of Minnesota }\end{array}$ & $\begin{array}{l}\text { General } \\
\text { population }\end{array}$ & $182 / 1,245$ & $\begin{array}{l}\text { Pathological } \\
\text { diagnosis; } \\
\text { case history }\end{array}$ & $\begin{array}{l}\text { Questionnaire } \\
\text { survey }\end{array}$ & $\begin{array}{l}\text { Age; } \\
\text { gender; } \\
\text { race }\end{array}$ & 5 \\
\hline $\begin{array}{l}\text { Benavente } \\
{[16], 2005}\end{array}$ & Spain & $\begin{array}{l}1998- \\
2002\end{array}$ & $\mathrm{M} / \mathrm{F}$ & NR & $\begin{array}{l}3 \text { pathological diagnosis } \\
\text { centers in } \\
\text { Spain }\end{array}$ & Inpatients & $574 / 616$ & $\begin{array}{l}\text { Pathological } \\
\text { diagnosis }\end{array}$ & $\begin{array}{l}\text { Face-to-face } \\
\text { survey }\end{array}$ & $\begin{array}{l}\text { Gender; } \\
\text { age; } \\
\text { medication } \\
\text { history }\end{array}$ & 6 \\
\hline $\begin{array}{l}\text { Cantor [17], } \\
1988\end{array}$ & USA & $\begin{array}{l}1980- \\
1983\end{array}$ & $\mathrm{M} / \mathrm{F}$ & $>30$ & $\begin{array}{l}\text { Cooperative Group } \\
\text { of Pathology among } \\
\text { several cities in Iowa } \\
\text { and Minnesota }\end{array}$ & $\begin{array}{l}\text { General } \\
\text { population }\end{array}$ & $622 / 1,245$ & $\begin{array}{l}\text { Pathological } \\
\text { diagnosis }\end{array}$ & $\begin{array}{l}\text { Questionnaire } \\
\text { survey }\end{array}$ & $\begin{array}{l}\text { Age; race; } \\
\text { occupation }\end{array}$ & 4 \\
\hline $\begin{array}{l}\text { Chiu [18], } \\
2004\end{array}$ & USA & $\begin{array}{l}1980- \\
1983\end{array}$ & M & NR & $\begin{array}{l}\text { Hospitals and } \\
\text { pathological diagnosis } \\
\text { centers of Iowa and } \\
\text { Minnesota }\end{array}$ & $\begin{array}{l}\text { General } \\
\text { population }\end{array}$ & $907 / 1,926$ & $\begin{array}{l}\text { Pathological } \\
\text { diagnosis; } \\
\text { case history }\end{array}$ & $\begin{array}{l}\text { Telephone } \\
\text { follow-up }\end{array}$ & $\begin{array}{l}\text { Smoking } \\
\text { history; } \\
\text { gender }\end{array}$ & 6 \\
\hline $\begin{array}{l}\text { Zahm [19], } \\
1992\end{array}$ & USA & $\begin{array}{l}1980- \\
1986\end{array}$ & $\mathrm{~F}$ & $>21$ & $\begin{array}{l}\text { Lymphoma Research } \\
\text { Group of Nebraska }\end{array}$ & $\begin{array}{l}\text { General } \\
\text { population }\end{array}$ & $441 / 1,432$ & $\begin{array}{l}\text { Pathological } \\
\text { diagnosis; } \\
\text { case history }\end{array}$ & $\begin{array}{l}\text { Telephone } \\
\text { follow-up }\end{array}$ & $\begin{array}{l}\text { Age; } \\
\text { gender; } \\
\text { race }\end{array}$ & 5 \\
\hline $\begin{array}{l}\text { Holly [20], } \\
1998\end{array}$ & USA & $\begin{array}{l}1991- \\
1995\end{array}$ & $\mathrm{M} / \mathrm{F}$ & $21-74$ & $\begin{array}{l}\text { Pathological } \\
\text { registrations from } 6 \\
\text { hospitals in San } \\
\text { Francisco }\end{array}$ & $\begin{array}{l}\text { General } \\
\text { population }\end{array}$ & $1,593 / 2,515$ & Case history & $\begin{array}{l}\text { Telephone } \\
\text { follow-up }\end{array}$ & $\begin{array}{l}\text { Age; } \\
\text { gender; } \\
\text { race }\end{array}$ & 6 \\
\hline $\begin{array}{l}\text { Miligi [21], } \\
2005\end{array}$ & Italy & $\begin{array}{l}1991- \\
1993\end{array}$ & $\mathrm{M} / \mathrm{F}$ & $20-74$ & 11 cities in Italy & $\begin{array}{l}\text { General } \\
\text { population }\end{array}$ & $611 / 828$ & Case history & $\begin{array}{l}\text { Face-to-face } \\
\text { survey }\end{array}$ & $\begin{array}{l}\text { Smoking } \\
\text { history; } \\
\text { gender; age; } \\
\text { occupation }\end{array}$ & 7 \\
\hline $\begin{array}{l}\text { Tavani [7], } \\
2005\end{array}$ & Italy & $\begin{array}{l}1985- \\
1997\end{array}$ & $\mathrm{M} / \mathrm{F}$ & $14-79$ & $\begin{array}{l}\text { Two provincial } \\
\text { pathological centers on } \\
\text { the east of Italy }\end{array}$ & Inpatients & $446 / 1,295$ & $\begin{array}{l}\text { Pathological } \\
\text { diagnosis }\end{array}$ & $\begin{array}{l}\text { Questionnaire } \\
\text { survey }\end{array}$ & $\begin{array}{l}\text { Smoking } \\
\text { history; } \\
\text { drinking } \\
\text { history; age }\end{array}$ & 6 \\
\hline $\begin{array}{l}\text { de Sanjosé } \\
{[22], 2006}\end{array}$ & Europe & $\begin{array}{l}1998- \\
2002\end{array}$ & $\mathrm{M} / \mathrm{F}$ & NR & $\begin{array}{l}\text { Cooperative Group } \\
\text { of Pathology in } \\
\text { Czech Republic, France, } \\
\text { Germany, Ireland, Italy, } \\
\text { and Spain }\end{array}$ & Inpatients & $1,702 / 2,417$ & $\begin{array}{l}\text { Pathological } \\
\text { diagnosis }\end{array}$ & $\begin{array}{l}\text { Face-to-face } \\
\text { survey }\end{array}$ & & \\
\hline $\begin{array}{l}\text { Morton [6], } \\
2007\end{array}$ & USA & $\begin{array}{l}1998- \\
2000\end{array}$ & $\mathrm{~F}$ & NR & $\begin{array}{l}\text { Epidemiological } \\
\text { investigation } \\
\text { institutions in } 4 \text { cities }\end{array}$ & $\begin{array}{l}\text { General } \\
\text { population }\end{array}$ & $1,321 / 1,057$ & $\begin{array}{l}\text { Pathological } \\
\text { diagnosis; } \\
\text { case history }\end{array}$ & & & \\
\hline $\begin{array}{l}\text { Zhang [23], } \\
2004\end{array}$ & USA & $\begin{array}{l}1996- \\
2000\end{array}$ & $\mathrm{~F}$ & $21-84$ & $\begin{array}{l}\text { Cancer Research Center } \\
\text { of Yale Uni- } \\
\text { versity; Connecticut } \\
\text { State Public Health Unit }\end{array}$ & $\begin{array}{l}\text { General } \\
\text { population }\end{array}$ & $601 / 717$ & $\begin{array}{l}\text { Pathological } \\
\text { diagnosis }\end{array}$ & & & \\
\hline $\begin{array}{l}\text { Wong [24], } \\
2010\end{array}$ & China & $\begin{array}{l}2003- \\
2008\end{array}$ & $\mathrm{M} / \mathrm{F}$ & $>18$ & $\begin{array}{l}\text { Collaborations among } \\
29 \text { hospital-sin Shanghai }\end{array}$ & Inpatients & $649 / 1,298$ & $\begin{array}{l}\text { Pathological } \\
\text { diagnosis }\end{array}$ & & & \\
\hline $\begin{array}{l}\text { Sangrajrang } \\
{[25], 2011}\end{array}$ & Thailand & $\begin{array}{l}2007- \\
2009\end{array}$ & $\mathrm{M} / \mathrm{F}$ & $17-81$ & $\begin{array}{l}3 \text { cancer research } \\
\text { institutes in } \\
\text { Thailand }\end{array}$ & Inpatients & $390 / 422$ & $\begin{array}{l}\text { Pathological } \\
\text { diagnosis; } \\
\text { case history }\end{array}$ & $\begin{array}{l}\text { Face-to-face } \\
\text { survey }\end{array}$ & & \\
\hline
\end{tabular}

Relationship between Hair Dye and Non-Hodgkin's Lymphoma 


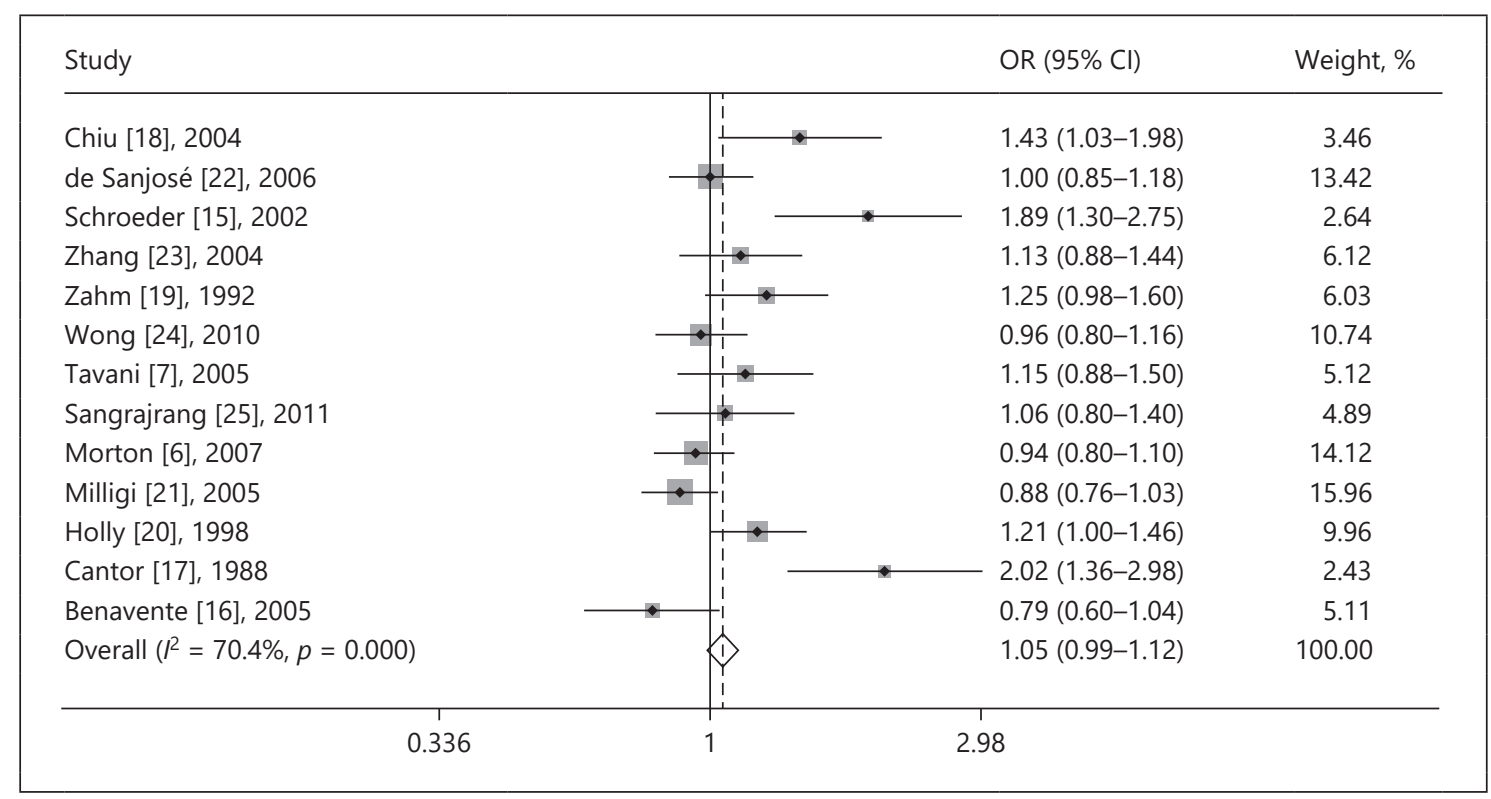

Fig. 2. Forest map for meta-analysis of 13 case control studies.

Table 2. Features of hair colorant use and NHL incorporated into the cohort study

\begin{tabular}{|c|c|c|c|c|c|c|c|c|c|c|}
\hline Study & Region & $\begin{array}{l}\text { Research } \\
\text { period }\end{array}$ & $\begin{array}{l}\text { Cohort } \\
\text { group }\end{array}$ & $\begin{array}{l}\text { Age, } \\
\text { years }\end{array}$ & $\begin{array}{l}\text { Cohort } \\
\text { study cases, } \\
n\end{array}$ & $\begin{array}{l}\text { Exposure } \\
\text { cases, } n\end{array}$ & $\begin{array}{l}\text { NHL } \\
\text { evaluation } \\
\text { criteria }\end{array}$ & $\begin{array}{l}\text { Hair colorant } \\
\text { use evaluation } \\
\text { standard }\end{array}$ & $\begin{array}{l}\text { Adjustment } \\
\text { factor }\end{array}$ & $\begin{array}{l}\text { Newcastle- } \\
\text { Ottawa Scale } \\
\text { quality score }\end{array}$ \\
\hline $\begin{array}{l}\text { Grodstein } \\
{[10], 1994}\end{array}$ & USA & $\begin{array}{l}1976- \\
1990\end{array}$ & $\begin{array}{l}\text { Inpatient } \\
\text { registration }\end{array}$ & $30-55$ & 99,067 & 114 & $\begin{array}{l}\text { Pathological } \\
\text { diagnosis }\end{array}$ & $\begin{array}{l}\text { Questionnaire } \\
\text { survey }\end{array}$ & $\begin{array}{l}\text { Age; gender; smoking } \\
\text { history }\end{array}$ & 7 \\
\hline
\end{tabular}

neity test ( $p<0.1, I^{2}=70.4 \%$ ), indicating that heterogeneity exists among these studies. When the random-effects model was employed to perform the meta-analysis, the corresponding results revealed that hair colorants are able to significantly increase the risk of onset of NHL (OR $1.12,95 \%$ CI $0.99-1.26$ ). These results were similar to the effect size achieved by the fixed-effects model merged and employed through the sensitivity analysis (OR 1.13; 95\% CI 1.01-1.28), and both were statistically significant. Hence, the analysis carried out in the present study was rather stable and credible (Fig. 2).

In addition, the 3 cohort studies incorporated in the present study had the following values: OR $1.09,95 \%$ CI 0.61-1.92; OR 1.10, 95\% CI 0.80-1.60; OR 1.10, 95\% CI
1.00-1.30. Relying on the meta-analysis approach mentioned above, 13 case control studies and 3 cohort studies were ultimately combined. $I^{2}$ was $79.7 \%$, indicating that there was heterogeneity among these diverse studies. Based on the random-effects model, OR was 1.14 and 95\% CI ranged between 1.01 and 1.29, which was statistically significant. These results are presented in Figure 3.

\section{Subgroup Analysis}

Gender

The OR value of NHL was 1.38 (95\% CI 1.01-2.20) for female hair colorant users, which was higher than that in male users (OR 1.04, 95\% CI 0.86-1.25; $p<0.01$ ). With regard to studies that covered male and female gender, 


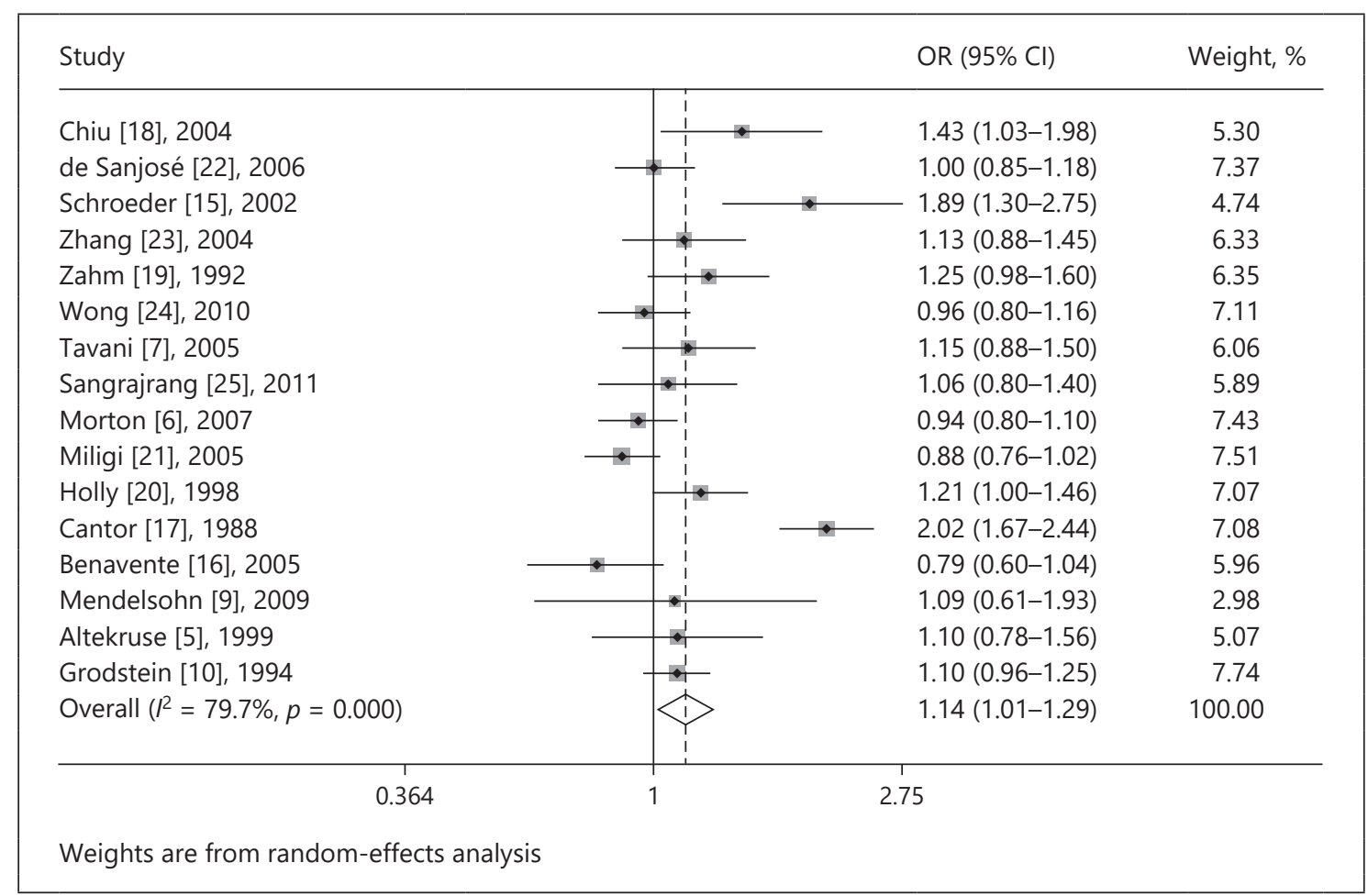

Fig. 3. Forest map for meta-analysis of 16 combined studies.

the OR value was 1.21 (95\% CI $0.95-1.43)$, and the heterogeneity test $\left(I^{2}=62.6 \%, p=0.03\right)$ indicated that these have moderate heterogeneity.

\section{Region}

Concerning the regional differences in these 16 articles, and relative to the OR values obtained from North America (OR 1.16, 95\% CI 0.97-1.80) and Europe (OR $1.07,95 \%$ CI $0.72-1.43$ ), the OR value from Asia was 1.27 (95\% CI 0.94-1.92). This indicates that NHL onset is associated with hair colorants, and there were no prominent differences among these $(p<0.01)$.

\section{Study Type}

The OR value of the case control study or cohort study was 1.13 (95\% CI $0.86-1.84$ ) or 1.16 (95\% CI $0.91-1.69$ ), respectively. Consistent with this result, the risk was deemed to be significant. Nevertheless, certain heterogeneity existed among these cohort studies $(p \leq 0.04)$.

\section{Frequency of Use of Hair Colorant}

The duration of use of hair colorant recorded in these articles was divided into 3 groups: $<10$ years, $10-20$ years, and $>20$ years. For usage of no less than 10 years, the cor- responding OR of NHL was 1.19 (95\% CI 0.90-1.88). In contrast, in people who used hair colorant for 10-20 years and $>20$ years, the OR values for this risk were 1.20 (95\% CI 1.02-1.95) and 1.34 (95\% CI 1.04-1.92), respectively. In line with these results, it was found that publication bias provided the heterogeneity $\left(I^{2}=78.1 \%\right)$. On this basis, we can speculate that the duration of use of hair colorants is linked to the onset of NHL to a certain degree.

\section{Research Quality}

Studies have shown that the quality of articles may not give rise to significant differences in evaluations on the association between hair colorant use and NHL. For studies with high and medium qualities, the OR value was 1.23 and 1.19, respectively. This indicates that hair colorants are associated with NHL, and that there were no significant differences among these relevant studies $(p<0.01$, in all cases).

\section{Source of the Research Sample}

The combined OR value for a study that included inpatients was 1.20 (95\% CI 0.84-1.69), while it was 1.14 (95\% CI 0.84-1.38) for studies that considered the gen- 


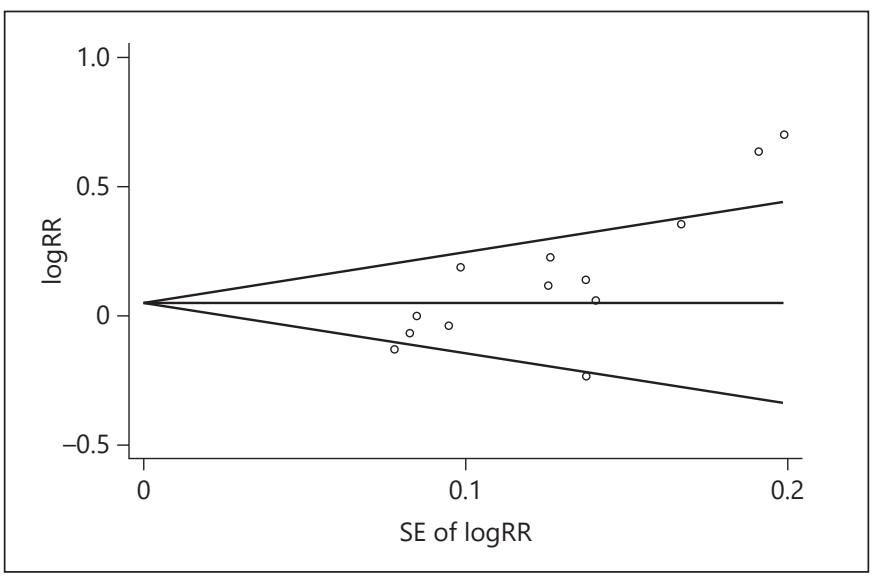

Fig. 4. Begg's funnel plot with pseudo 95\% CIs for publication bias assessment. SE, standard error.

eral population as the control group. However, the difference was not statistically significant $\left(I^{2}=36.5 \%\right)$.

Publication Bias and Sensitivity Analysis

Basically, no significant graphic and statistical bias was identified through the rank correlation analysis (Begg's method) of the funnel plot (Fig. 4). In addition, according to Begg's rank correlation check, articles that involved hair colorant use and NHL risk meta-analyses also revealed no obvious publication bias.

\section{Discussion}

Since the 1950s, hair colorants have been extensively used and have become increasingly popular among the youth. These colorants can be divided according to coloring time: permanent, semipermanent, and temporary hair colorants $[4,17,26]$. Some components with deformed carcinogenic ingredients, such as propylene glycol, sodium carbonate, toluene, and p-phenylenediamine, have attracted attention, and people have been made aware of their harmful health effects. Earlier studies on hair colorants found that these ingredients may likely induce lymphoma, carcinoma of the urinary bladder, and breast cancer $[3,8]$.

P-phenylenediamine, as the major component of frequently used oxidation hair colorants, has an extremely strong affinity for keratin in hair, and the color fixation process is also the oxidation process of $\mathrm{p}$-phenylenediamine [27]. It is not only the most effective component of hair colorants, but also poses severe health hazards; $\mathrm{p}$ - phenylenediamine can increase the risk of breast cancer and pituitary tumors. In 2007, a study on p-phenylenediamine dosage [28] indicated that continuous exposure to p-phenylenediamine in large or small doses can lead to toxicity accumulation in the skin, which exerts an adverse impact on human health. Thus, it is apparent that hair dyes are inherent with potential toxic effects. In addition, due to heating during the application of hair dyes, the concentration of hair dye raw material increases; when colorants are used frequently, chlorobenzenes may be induced to penetrate into the blood circulation through the scalp and may reach the bone marrow. On this basis, hair colorant components are speculated to act on hematopoietic stem cells and the bone marrow microenvironment for a long period of time, which further damages the former and incurs variations in the latter $[29,30]$. Research has shown that some enzymes and genes are changed during the process of hair coloring, which may induce disorders of the lymphatic system, followed by lymphoma $[6,27]$.

The results of the present meta-analysis show that relative to the group of subjects that did not use any hair colorants, the use of hair colorants was correlated to the onset of NHL to a certain extent. When compared with male users, female users have a higher risk of NHL. This potential influencing factor may be due to a larger base of female subjects in this analysis, together with the higher frequency of using these products. From the perspective of duration of use hair colorant, the duration is linearly related to NHL risk, especially for those who have used hair colorants for more than 20 years. Hair colorants reported by studies before 1998 were strongly associated with NHL, and the corresponding reason may be the raw material and its processes. Although these incorporated articles had diverse study design types, the diversity factor between these articles was not large.

Due to the large sample sizes in recent articles, the results of the present study are significant. In the present report, the risk assessment for hair colorant use and NHL was thoroughly studied based on the subgroup analysis of region, gender, and use frequency. However, there were limitations in gathering previously published articles and performing the meta-analysis. First, the study objects in the present study were from articles published in English or Chinese. Although no bias was discovered by Egger's test, it could not be concluded that all articles are independent of any potential bias. Second, in the articles included in this analysis, various questionnaires were specifically designed for hair colorants; differences in color and coloring time of hair colorants may have 
caused the evaluation to be incorrect. Furthermore, telephone or E-mail follow-ups for hair colorant use were also provided with bias. Third, considering the small quantities of some of the subgroup analysis data, bias may exist despite the fact that it was carried out in strict accordance with the design criteria. Finally, the article types incorporated into the present study were case-control and cohort studies. Hence, methodological discrepancies and confounding factors would have likely affected the final outcome.

The limitations mentioned above weaken the association between hair colorants and NHL to a certain degree, although without influencing the results of the entire meta-analysis. Overall, and in the majority of the subgroup analysis, no prominent heterogeneity existed among the studies. In addition, the present study does not have publication bias.

\section{Conclusion}

The present study reveals that in comparison with male users of hair colorants, females have a higher risk of onset of NHL. In addition, within a certain period, the use of hair colorant positively correlated with the risk of onset of NHL, especially when the duration of use exceeded 20 years, which may give rise to increased risk of onset of NHL. Therefore, exposure to hair colorants should be reduced as much as possible, especially in the population that frequently uses hair colorants or has used these colorants for longer durations. Alternatively, the use of relatively safe hair dyes obtained from plants can be recommended.

\section{Disclosure Statement}

The authors have no conflicts of interest to declare.

\section{References}

1 Chiu BC, Hou N. Epidemiology and etiology of non-Hodgkin lymphoma. Cancer Treat Res. 2015;165:1-25.

2 Linet MS, Vajdic CM, Morton LM, de Roos AJ, Skibola CF, Boffetta P, et al. Medical history, lifestyle, family history, and occupational risk factors for follicular lymphoma: the InterLymph Non-Hodgkin Lymphoma Subtypes Project. J Natl Cancer Inst Monogr. 2014 Aug;2014(48):26-40.

3 Zhang Y, Kim C, Zheng T. Hair dye use and risk of human cancer. Front Biosci (Elite Ed). 2012 Jan;4(1):516-28.

4 Tafurt-Cardona Y, Suares-Rocha P, Fernandes TC, Marin-Morales MA. Cytotoxic and genotoxic effects of two hair dyes used in the formulation of black color. Food Chem Toxicol. 2015 Dec;86:9-15.

5 Altekruse SF, Henley SJ, Thun MJ. Deaths from hematopoietic and other cancers in relation to permanent hair dye use in a large prospective study (United States). Cancer Causes Control. 1999 Dec;10(6):617-25.

6 Morton LM, Bernstein L, Wang SS, Hein DW, Rothman N, Colt JS, et al. Hair dye use, genetic variation in $\mathrm{N}$-acetyltransferase 1 (NAT1) and 2 (NAT2), and risk of nonHodgkin lymphoma [published Online First: Epub Date]. Carcinogenesis. 2007 Aug;28(8): 1759-64.

7 Tavani A, Negri E, Franceschi S, Talamini R, Serraino D, La Vecchia C. Hair dye use and risk of lymphoid neoplasms and soft tissue sarcomas [published Online First: Epub Date]. Int J Cancer. 2005 Feb;113(4):629-31.
8 Koutros S, Silverman DT, Baris D, Zahm SH, Morton LM, Colt JS, et al. Hair dye use and risk of bladder cancer in the New England bladder cancer study. Int J Cancer. 2011 Dec; 129(12):2894-904

9 Mendelsohn JB, Li QZ, Ji BT, Shu XO, Yang G, Li HL, et al. Personal use of hair dye and cancer risk in a prospective cohort of Chinese women. Cancer Sci. 2009 Jun;100(6):108891.

10 Grodstein F, Hennekens CH, Colditz GA, Hunter DJ, Stampfer MJ. A prospective study of permanent hair dye use and hematopoietic cancer. J Natl Cancer Inst. 1994 Oct;86(19): 1466-70.

11 Zhang Y, Sanjose SD, Bracci PM, Morton LM, Wang R, Brennan P, et al. Personal use of hair dye and the risk of certain subtypes of nonHodgkin lymphoma. Am J Epidemiol. 2008 Jun;167(11):1321-31.

12 Zhang J, Yu KF. What's the relative risk? A method of correcting the odds ratio in cohort studies of common outcomes. JAMA. 1998 Nov;280(19):1690-1.

13 DerSimonian R, Laird N. Meta-analysis in clinical trials. Control Clin Trials. 1986 Sep; 7(3):177-88.

14 Egger M, Davey Smith G, Schneider M, Minder C. Bias in meta-analysis detected by a simple, graphical test. BMJ. 1997 Sep;315(7109): 629-34.

15 Schroeder JC, Olshan AF, Baric R, Dent GA, Weinberg CR, Yount B, et al. A case-control study of tobacco use and other non-occupational risk factors for $\mathrm{t}(14 ; 18)$ subtypes of non-Hodgkin's lymphoma (United States). Cancer Causes Control. 2002 Mar;13(2):15968.
16 Benavente Y, Garcia N, Domingo-Domenech E, Alvaro T, Font R, Zhang Y, et al. Regular use of hair dyes and risk of lymphoma in Spain. Int J Epidemiol. 2005 Oct;34(5):111822.

17 Cantor KP, Blair A, Everett G, VanLier S, Burmeister L, Dick FR, et al. Hair dye use and risk of leukemia and lymphoma. Am J Public Health. 1988 May;78(5):570-1.

18 Chiu BC, Weisenburger DD, Zahm SH, Cantor KP, Gapstur SM, Holmes F, et al. Agricultural pesticide use, familial cancer, and risk of non-Hodgkin lymphoma. Cancer Epidemiol Biomarkers Prev. 2004 Apr;13(4):525-31.

19 Zahm SH, Weisenburger DD, Babbitt PA, Saal RC, Vaught JB, Blair A. Use of hair coloring products and the risk of lymphoma, multiple myeloma, and chronic lymphocytic leukemia. Am J Public Health. 1992 Jul;82(7): 990-7.

20 Holly EA, Lele C, Bracci PM. Hair-color products and risk for non-Hodgkin's lymphoma: a population-based study in the San Francisco bay area. Am J Public Health. 1998 Dec;88(12):1767-73.

21 Miligi L, Costantini AS, Benvenuti A, Veraldi A, Tumino R, Ramazzotti V, et al. Personal use of hair dyes and hematolymphopoietic malignancies. Arch Environ Occup Health. 2005 Sep-Oct;60(5):249-56.

22 de Sanjosé S, Benavente Y, Nieters A, Foretova L, Maynadié M, Cocco PL, et al. Association between personal use of hair dyes and lymphoid neoplasms in Europe [published Online First: Epub Date]. Am J Epidemiol. 2006 Jul;164(1):47-55.
Relationship between Hair Dye and Non-Hodgkin's Lymphoma
Med Princ Pract 2019;28:222-230

DOI: $10.1159 / 000496447$ 
23 Zhang Y, Holford TR, Leaderer B, Boyle P, Zahm SH, Flynn S, et al. Hair-coloring product use and risk of non-Hodgkin's lymphoma: a population-based case-control study in Connecticut. Am J Epidemiol. 2004 Jan; 159(2):148-54.

24 Wong O, Harris F, Wang Y, Fu H. A hospitalbased case-control study of non-Hodgkin lymphoid neoplasms in Shanghai: analysis of personal characteristics, lifestyle, and environmental risk factors by subtypes of the WHO classification [published Online First: Epub Date]. J Occup Environ Med. 2010 Jan; 52(1):39-53.
25 Sangrajrang S, Renard H, Kuhaprema T, Pornsopone P, Arpornwirat W, Brennan P. Personal use of hair dyes-increased risk of non-Hodgkin's lymphoma in Thailand. Asian Pac J Cancer Prev. 2011;12(9):2393-6.

26 La Vecchia C, Tavani A. Epidemiological evidence on hair dyes and the risk of cancer in humans. Eur J Cancer Prev. 1995 Feb;4(1): 31-43.

27 Guo H, Bassig BA, Lan Q, Zhu Y, Zhang Y, Holford TR, et al. Polymorphisms in DNA repair genes, hair dye use, and the risk of nonHodgkin lymphoma. Cancer Causes Control. 2014 Oct;25(10):1261-70.
28 White JM, Basketter DA, Pease CK, Sanders DA, McFadden JP. Intermittent exposure to low-concentration paraphenylenediamine can be equivalent to single, higher-dose exposure. Contact Dermat. 2007 May;56(5):262-5.

29 Nohynek GJ, Fautz R, Benech-Kieffer F, Toutain $\mathrm{H}$. Toxicity and human health risk of hair dyes. Food Chem Toxicol. 2004 Apr; 42(4):517-43.

30 Blair A, Linos A, Stewart PA, Burmeister LF, Gibson R, Everett G, et al. Comments on occupational and environmental factors in the origin of non-Hodgkin's lymphoma. Cancer Res. 1992 Oct;52(19 Suppl):5501s-2s. 